\title{
Maintenance of an Efficient and Equilibrated Immune System Through the Novel Use of Natural Health Products: Synopsis of a Symposium
}

\author{
Pierre S. Haddad ${ }^{\star}$, Geneviève Beauchamp, Geneviève Côté and Michel Boivin \\ Department for an Integrated Approach to Prevention, Fondation Lucie and André Chagnon, 2001 McGill \\ College Avenue, Suite 1000, Montreal, Quebec, Canada, H3A 1G1
}

\section{The Instigator and the Vision}

The philanthropic Lucie et André Chagnon Foundation was created in October 2000 with the aim of improving quality of life by centering on the prevention of poverty and disease. In order to have a significant and novel impact, the Foundation concentrated its efforts on the margins of the modern medicine mainstream and identified the immune system and natural health products as promising perspectives to explore. It thus convened a group of 20-30 experts in immunology, natural health products (NHPs) and related fields for a day-and-a-half symposium held at the Hôtel XIXe Siècle, Montreal, Quebec, Canada, on September 23 and 24, 2004 to discuss the validity of these approaches and the most promising avenues to encourage in the future.

\section{The Topics of Discussion}

During the day-and-a-half symposium, the group of 20-30 experts discussed the appropriateness of targeting the immune system to prevent chronic diseases, assessed the experimental tools and models available to researchers, and evaluated the most promising NHPs to act in prevention. In conformity with the NHP definition of the Natural Health Product Directorate of Health Canada, the following products were considered for their immunomodulatory potential: probiotics, products of animal origin (e.g. milk proteins, bovine colostrum and thymic extracts), vitamins and minerals, isolates (e.g. fatty acids) and herbal products (e.g. Echinacea spp., $P$. ginseng, green tea and others).

For reprints and all correspondence: Pierre S. Haddad, Department for an Integrated Approach to Prevention, Fondation Lucie and André Chagnon, 2001 McGill College Avenue, Suite 1000, Montreal, Quebec,

Canada, H3A 1G1 Email: haddadp@fondationchagnon.org

\section{Consensus and Future Research Directions}

Participants were in agreement on the following points: (i) the immune system is immensely complex but its dysfunction has been clearly implicated in the aetiology of various chronic diseases; (ii) the evidence base supporting the immunomodulatory effects of NHPs is of variable quality and undermined by the lack of clinical trial success related to poor study protocols and weak quality control of source materials; (iii) standardization of test methods and of source materials would be crucial to identify and distinguish effective from ineffective immune modulating NHPs; (iv) certain NHPs such as probiotics, micronutrients and plants show great promise in the prevention of chronic diseases related to immune dysfunction; and (v) research in NHPs is largely under funded.

Points identified as requiring further attention were as follows. (i) How should NHPs be promoted for the prevention of chronic diseases and to what target population should such a strategy be promoted? Partial answers provided were (a) to develop research networks including scientists from various fields (e.g. research 'pillars' of the Canadian Institutes of Health Research; basic, clinical, population health and health system research); and (b) to target children and the elderly in whom immune function is developing or compromised. (ii) What biomarkers should be measured to determine immune function equilibrium? Partial answers provided were (a) to use a constellation of biomarkers, including natural killer cells and cytokines; and (b) to explore novel blood-borne markers such as microparticles.

\section{List of Participants}

John Thor Arnason, Univerity of Ottawa, ON.

Valerie Assinewe, Natural Health Products Directorate, Health Canada, Ottawa, ON.

(C) The Author (2005). Published by Oxford University Press. All rights reserved.

The online version of this article has been published under an open access model. Users are entitled to use, reproduce, disseminate, or display the open access version of this article for non-commercial purposes provided that: the original authorship is properly and fully attributed; the Journal and Oxford University Press are attributed as the original place of publication with the correct citation details given; if an article is subsequently reproduced or disseminated not in its entirety but only in part or as a derivative work this must be clearly indicated. For commercial re-use, please contact journals.permissions@oupjournals.org 
Yossi Av-Gay, University of British Columbia, BC.

George Azar, Université de Montréal, QC.

Roch Bernier, Chagnon Foundation, QC.

Richard Béliveau, Université du Québec à Montréal, QC.

Michel Boivin, Université de Montréal and Chagnon Foundation, QC.

Yvan Boutin, INAF (Nutraceutical and Functional Foods Institute of Laval University) and CEGEP Lévis-Lauzon, QC.

André Chagnon, Chagnon Foundation, QC.

Jean-Paul Collet, McGill University, QC.

Edwin L. Cooper, UCLA, CA.

Alain Cuerrier, Montreal Botanical Garden, QC.

Simon Groom, McGill University and CTBR Inc., QC.

Pierre S. Haddad, Université de Montréal and Chagnon Foundation, QC.

Sid Katz, University of British Columbia, BC.
Darshan Kelley, USDA and University of California at Davis, CA.

Johanna W. Lampe, Fred Hutchison Cancer Research Center, WA.

Tim Lee, Dalhousie University, NS.

Irma Lemaire-Bernatchez, Univerity of Ottawa, ON.

Antonio Martin, Tufts University, MA.

Sandra Miller, McGill University, QC.

Judes Poirier, McGill University, QC.

Marie Provost, La Clef des Champs (Herbalist).

Charles Ramassamy, INAF, INRS-IAF (Institut National de Recherche Scientifique, Institut Armand-Frappier), QC. Marek Rola-Pleszczunski, Université de Sherbrooke, QC.

Denis Roy, INAF, Université Laval, QC.

Ernest Seidman, Université de Montréal, QC.

Bhagirath Singh, University of Western Ontario, ON. 


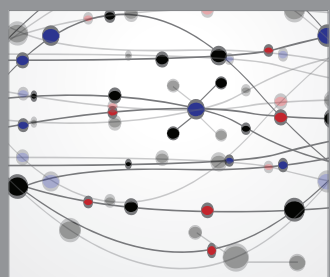

The Scientific World Journal
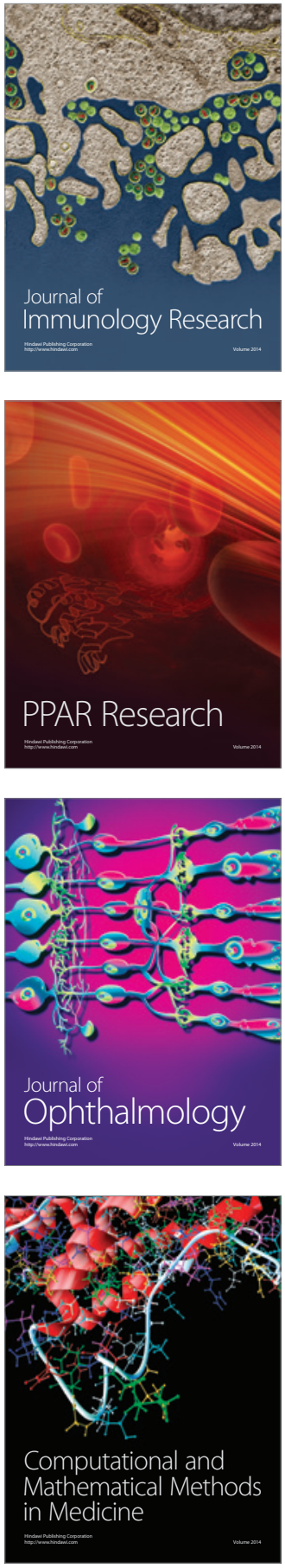

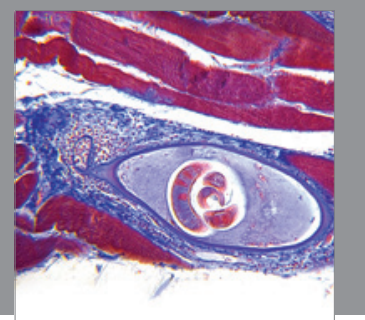

Gastroenterology

Research and Practice
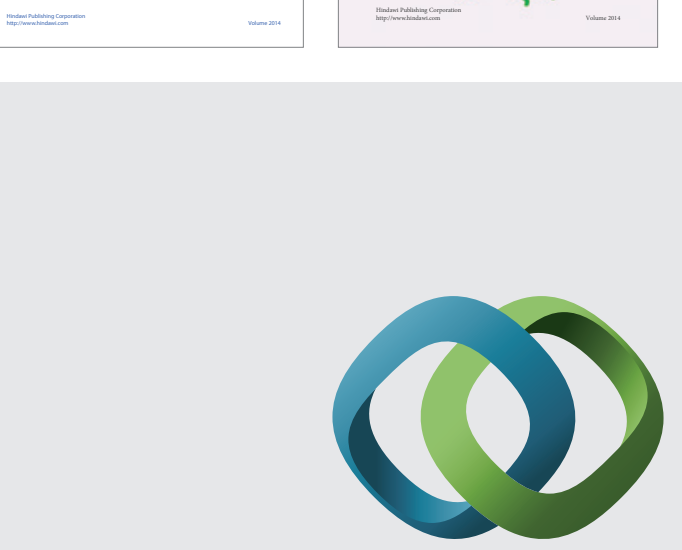

\section{Hindawi}

Submit your manuscripts at

http://www.hindawi.com
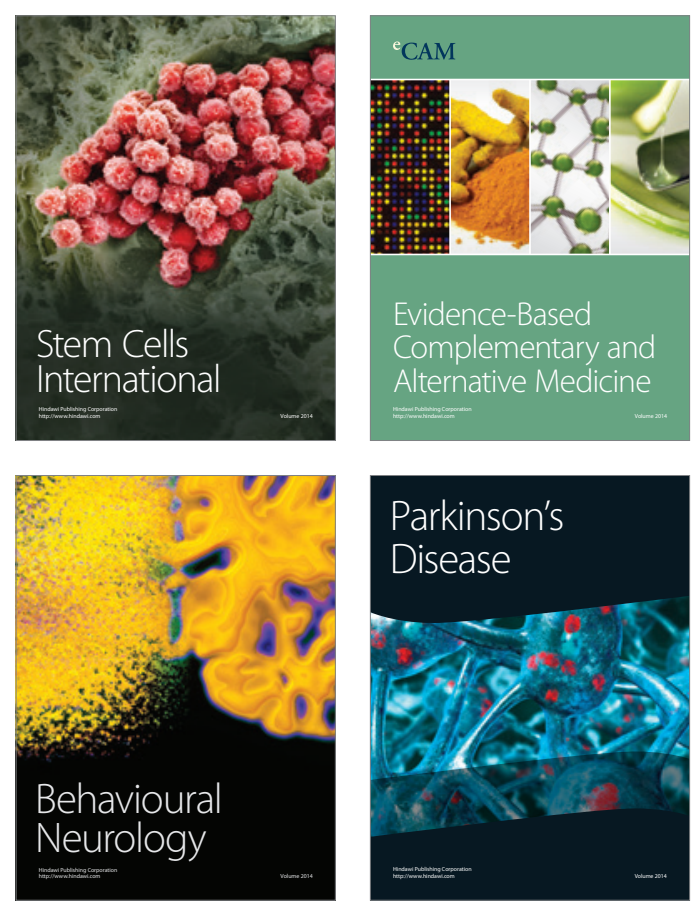

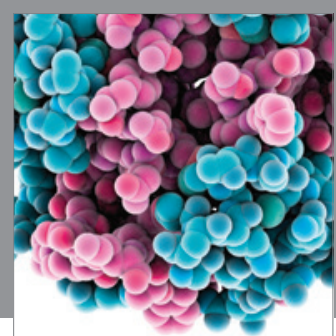

Journal of
Diabetes Research

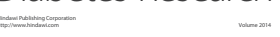

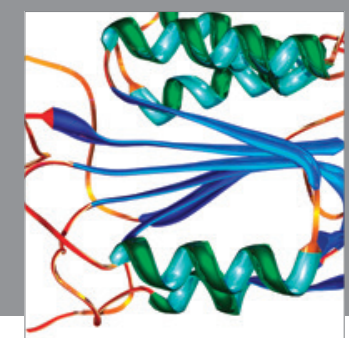

Disease Markers
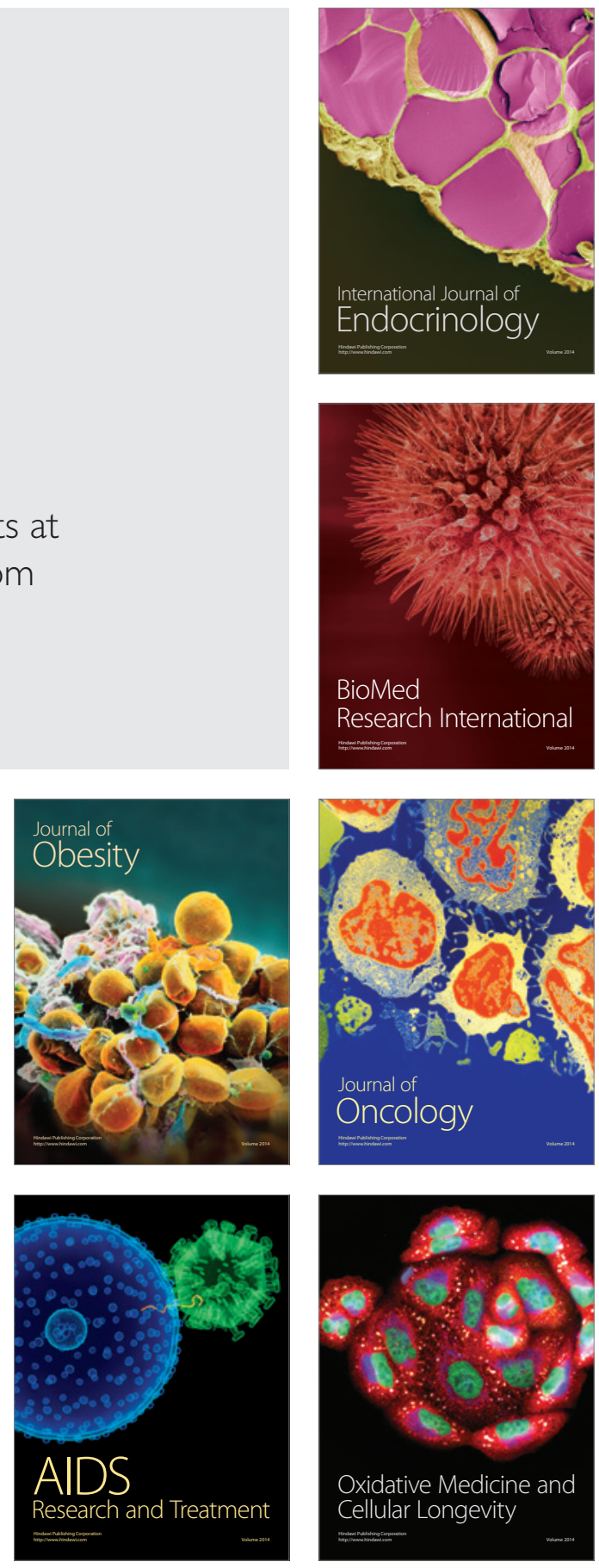